Przegląd Badań Edukacyjnych Educational Studies Review

ISSN 1895-4308

nr 28 (1/2019), s. 111-147

METAANALIZY

BADAN

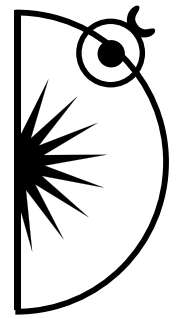

Sławomir Pasikowski

ORCID: 0000-0002-0768-1596

The University of Lodz, e-mail: slawomir.pasikowski@uni.lodz.pl

\title{
Individual Methodological Orientations - Theoretical Background and a Model of the Phenomenon
}

http://dx.doi.org/10.12775/PBE.2019.007

\begin{abstract}
The aim of the article is to present the issues of individual methodological orientations as well as to propose a model that can be the basis for making an empirical characterization of the phenomenon. Therefore, the theoretical background showing the semantic positioning of the concept in the network of synonymous concepts was drawn. Then, the theoretical construct and a model based on the category of opposition in the methodological discourse were derived based on the theory of Kazimierz Obuchowski's orientation codes and James J. Gibson's affordance concept. In the presentation of the model, an integrated system of three planes was used. Each of them serves to reflect the characteristics of the elements of cognition which takes place in the course of the undertaken research practice. The assumption of continuity of features allows for modelling individual methodological orientations in a transversal manner with respect to the divisions and classifications in the social sciences methodology. This creates the possibility of building individual characteristics, e.g. for the purpose of matching methodological education.
\end{abstract}

Keywords: individual methodological orientations, methodology, dichotomy principle, oppositions, ambivalence.

\section{Introduction}

Orientation is a term with a broad scope of meaning. In the methodological sense, it is usually used intuitively and most often to designate a theoretical ap- 
proach or a theoretical trend, a research strategy or a paradigmatic inclination (cf. Palka, 1998 a, b, 2018; Ritter, 2012). The root of this term refers to the Latin term "oriens" meaning "sunrise" or "east". It is a term closely associated with searching for directions of the world. Depending on the context, however, its meaning may change, although the common denominator, which is the direction or vector of movement, remains essential. From the point of view of the language of scientific disciplines, perhaps the most-established position of the term "orientation" is that in the biological dictionary. There, orientation means the ability of an organism to direct its body and move towards a stimulus or in the opposite direction, while also taking into account other environmental influence (Barrows, 2011). In this context, when the subject of the description is the movement of plants the used term is tropism, but when the description refers to the movement of animals and microorganisms the used term is taxis or tactism. There is also the practice of using the term "guiding" (Dusenbery, 2009, p. 221) and kinesis (Braun \& Hemmersbach, 2008) in similar contexts. However, the basic meaning of all these terms remains the same, and the only difference between them consists primarily in referring to a different mechanism of turning and determining the vector of motion of organisms.

It is also worth reaching to the roots of these notions, whose origin is associated with tropism - a concept with over two hundred years of tradition. The concept of tropism was introduced by Thomas Knight and developed by Charles Darwin (Gilroy, Masson, 2008, p. xiii). According to this theory, the directed growth of sedentary organisms (most often plants) is stimulated by a vector of an active stimulus, without which the development and survival of such an organism would not be possible.

Mentioning the above findings may enrich the repertoire of associations related to the idea of orientation by references to the issue of transmission and consolidation of thinking and acting patterns. Turning in this way to sciences having man as their subject, it becomes apparent that the term "orientation" has a much less precise reference in this domain. It is usually used in the sense of propensity, direction and preferences (Grzelak, Jarymowicz, 2000; Murphy, Ackermann, \& Handgraaf, 2011; Van Lange, De Bruin, Otten, \& Joireman, 1997), worldview, beliefs and assessments (Reykowski, 2000) or simply consciousness $^{1}$ (Kielar-Turska, 2000). However, one can indicate examples of its

1 This may serve as an argument for the statement on the legitimacy of taking into account the closer relationship between the idea of individual methodological orientation and the concept of methodological awareness. 
dissemination in a more specific form. This is the case for the concept of sexual orientation and the psychiatric concept of orientation referring to the issue of maintaining contact with reality, as contrasted with the concept of confusion (amentia), which in turn expresses the incoherence of thinking, a limited contact with the environment and a loss of ability to recognize the situation (Bilikiewicz, 2000; Groth-Marnat, 2003; Jaroszyński, 1987). The term "orientation" is also used in the theory of clinical psychology in describing approaches to modelling health and illness (Plante, 2005; Sęk, 2001). Thus, it is connected with metatheoretical issues and quite rightly identified with the field of the methodology of science.

An elaborated concept of orientation can be found in the context of issues developed in the field of social psychology. Indeed, social orientations are defined as implicit normative assumptions (Reykowski, 1990) forming a system of general principles governing the processing of social information. They would be produced socially, deeply internalized by the subject and strongly enmeshed into his or her cognitive structure, playing the role of "certainties" determining the equilibrium of the world image. Such individual social orientations would be "generalized tendencies to perceive, value, feel and react to social reality" (Ziółkowski, 1990, p. 57). When this idea is considered from the point of view of individual processing of information, the selectivity of perception and perceptual setting are strongly emphasized. This was used by Krzysztof Mudyń (2007) to operationalize his construct of private ontological orientations, drawing at the same time attention to the possibility of considering the sense of the concept of orientation in three aspects. In metaphorical sense, orientation is the depth of field characteristic of an individual and the type of cognitive filters used by them. In the theoretical aspect, it is a tendency to selectively focus on certain aspects of reality and activity, leading to the conviction that the cognitively processed content is real. In the operational aspect in turn, orientation is what is measured by instruments designed to reproduce this feature (Mudyń, 2007, p. 122). This is a distinction which can be helpful in developing the concept of methodological orientations, as it offers approximations of possible conceptualisations: as a filter, a theoretical construct, and as an object of empirical observation. The fact that cognitive approaches are prevalent in the orientation descriptions referred to so far, is worth particular attention. 


\section{The concept of methodological orientation in the terminological field of research on the methodology of science}

In works devoted to issues in the field of general methodology, the term orientation is rarely used in a precise form. Generally, it appears in the context of such concepts as current, approach, positions, stands, school of thought, tendency, theoretical direction and paradigm (e.g. Chojnicki, 2000; Kubinowski, 2017; Guba, Lincoln, 2005; Pasikowski, 2016). The latter term includes a theoretical issue and is related to the guidelines governing the research practice, and therefore seems to be mostly associated with properties that may also contribute to the connotation of "methodological orientation". However, the concept of methodological orientation would have a considerably narrower meaning. Sometimes the concept of orientation is presented as an instrument for research identification and self-identification (Urbaniak-Zając, Piekarski, 2003, p. 17), especially when it is employed to designate subjective and collective inclinations towards specific research strategies or approaches, e.g. qualitative, quantitative, or mixed (cf. Creswell, 2014; Pilch, Bauman, 2010), sets of methodological premises sometimes referred to as research paradigms (Creswell, 2014), or research wings, i.e. hermeneutic-phenomenological studies and empirical studies (Palka, 1998). However, it is extremely difficult to find attempts aimed at developing these ideas. Nevertheless, an elaborated, and at the same time unique concept of methodological orientations can be indicated, understood as sets of general ontological and epistemological assumptions (Gnitecki, 2002, 2006a). It will be described in more detail further on in this text.

At this point, it is worth recalling the concepts that can be more or less intuitively associated with the category of individual methodological orientations. This is primarily the case with methodological preferences or a proneness to a specific methodology. The issue of methodological preferences was even operationalized in the form of the Profile of Individual Preferences of an Investigator (PIPB-80) in the study by Czesław S. Nosal (1986), and the proneness to use research and its results in professional practice and their positive evaluation, defined as research orientation, has long been regarded as a construct and a property significant in terms of labor professionalization (Bolin, Lee, GlenMaye, Yoon, 2012; Bonner \& Sando, 2008; Peachey, Baller, \& Schubert, 2018). We can also recall the notion of cognitive orientations (Juszczyk, 2013), research orientations in a theoretical and methodological sense (Silverman, 2015), individual epistemologies (Nosal, 1992; Royce \& Mos, 1980), psychoepistemological styles (Desimpelaere, Sulas, Duriez, Hutsebaut, 1999), cogni- 
tive ecotypes (Błaszak, 2013), philosophical and methodological beliefs (Sheehan, Johnson, 2012), epistemological and ontological beliefs (Schraw, 2013), methodological awareness (Brzeziński, 1978; Spendel, 2005), methodological culture (Knyazheva, 2012; Pasikowski, 2014), attitudes towards methodology and science (Flakus, 2017; Papanastasiou, 2005; Povee \& Roberts, 2014; Povee $\&$ Roberts, 2015), or the concept of private ontological orientations discussed above (Mudyń, 2007). This is probably only a proximal part of the semantic network in which the concept of individual methodological orientations shall be embedded. However, to avoid a "race of categories", which is a symptom of the weakening link between theory and empiricism in social sciences (Banaszak, 2017), it should be pointed out that despite visible correspondences, the number of mentioned concepts cannot be reduced. Most of them are different from the others, both semantically and on the ground of operationalization. The conceptualization of individual methodological orientations reveals a space in the aforementioned network which can be named. However, this intuition is confronted, first and foremost, by constructs not related directly to the field of methodological reflection. In these, we recognize the theory of orientation codes by Kazimierz Obuchowski, and following the topic of the integration of cognition and action discussed in it, the concept of affordance developed on the basis of the ecological theory of knowledge by James J. Gibson. They will be described in the next section.

\section{Theoretical implications for the model of individual methodological orientations}

\section{a. Conception of methodological orientations by Janusz Gnitecki}

Methodological orientations were defined as sets of general ontological and epistemological assumptions that determine how to conduct scientific research and on what pattern of rationality to base it, what research methods to employ, how to organize research activities to form the process of scientific cognition and what kind of knowledge to prefer and generate (Gnitecki, 2002, 2006a). On the basis of these reference areas, Janusz Gnitecki distinguished four basic methodological orientations: inductionism, deductionism, essentialism and anarchism, and four types of knowledge referring correspondingly to them, i.e. episteme, doxa, essence and paradigm. An important place in Gnitecki's conception is occupied by the principle of ambivalence which justifies the inalienable ambiguity of reality, fluctuations, oscillations and fuzziness of borders occurring in the world, including the world of ideas. The principle of ambiva- 
lence forms the basis for transcending the blocking effect of oppositions in which basic methodological orientations develop (Gnitecki, 1998, 2006 a, b). Cognition and knowledge, as a result of the former, are petrified if they are limited to a single point or position. In order to remain relevant to dynamic reality, they cannot be deprived of their motion. For this reason, Gnitecki promotes care for the oscillation and pulsation of categories, and for balancing of oppositions and not getting rid of them (Gnitecki, $2006 \mathrm{a}, \mathrm{b}$ ). The author is not alone in his view here (cf. the idea of critical rationalism by Bachelard (2000)). From the point of view of the model of individual methodological orientations, the principle of ambivalence is the most inspiring element of Gnitecki's conception.

In contrast to the principle of ambivalence, there is the principle of opposition and dichotomization (cf. Gnitecki, 1998). The latter principle is very common in cognition and scientific thinking, and consists in distinguishing the language and the world and treating this distinction as the basis for rational discourse (Mitterer, 1996). Dichotomous distinguishing is introduced already at the first stages of the process of socialization of the individual, and it is based on an arbitrarily imposed ideation, although there are also arguments that there are factors conditioning the dichotomization in the individual and group perception and thinking which go beyond socialization (cf. Biedrzycki, 1998; Brown, 2004; Levi-Strauss, 2011). One of strong arguments is provided by the list of human cultural universals (Brown, 2004; Pinker, 2005). Alongside other universals from the group of those connected with cognitive activity and data organizing properties of the mind, it contains binary discrimination. These properties include, inter alia: classification, creation of nomenclature, planning, reasoning and explanation, logical concepts, creation of tools, measuring, numbers and counting, the concept of part and whole, polysemy and antonyms. Without the majority of the aforementioned, scientific research activity would be difficult to imagine. What is more, the binary distinctions and the continuum form one of the main features organizing the process of scientific cognition. Also methodological reflection is organized through these universal concepts. Except for information provided in this text, examples can be found in almost every methodology manual.

In everyday life, the rules of dichotomous thinking and speaking are subject to internalization and, as a result, they are treated as axioms of cognition, and the dichotomous structure itself is seen as an obvious property of the cognised reality. Such a situation turns out to be a pedagogical problem, because in the search for truth and in upbringing, dichotomization necessarily involves the need to favor one option only. Hence proposals such as the non-dualizing 
mode of speaking by Mitterer (1996, 2004). The intention of non-dualizing speech is to create obstacles to the creation of paradigms and the dualization procedure on which it is based. Mitterer claims that theories, concepts and models built within a particular paradigm, even if they are subject to change, are nevertheless focused on preserving some version of truth they are supposed to serve. In their strenuous defence of some truth, they are dogmatic. For this reason, the author describes paradigms as paradogmas (Mitterer, 1996, p. 9). My position is not that radical. However, I do notice the great potential for sensitizing the reflection of Mitterer and other authors who pay attention to the issues of dichotomization, opposition and antinomy (e.g. Badach \& Smyk, 2016; Bateson, 1996; Godoń, 2012; Levi-Strauss, 2011; Rydlewski, 2016; Sojak, 2004; Stomma, 2002; Wilden, 1980; Witkowski, 2013). Dichotomization itself is not a disadvantage, because after all it forms the basis for creating mental representations, but sticking with it is (cf. Bachelard, 2000). Besides, oppositions are credited with a creative role in scientific cognition and methodological reflection (Bachelard, 2000; Kamiński, 1992, p. 161), as long as they do not prevent us from being aware of the dynamics of this cognition, its subject matter and its contextual nature (Urbaniak-Zając, 2013, p. 48). Otherwise, they are controversial (Hajduk, 2017; Malewski, 2017). Dichotomization and dichotomies in scientific language and thinking can be used to identify individual methodological orientations. Indeed, since dichotomies reflect the process of reality structuring, they can be employed to define the field and watch the movement, even symbolic, which in this opposition-structured field is produced by the subject.

\section{b. Theory of orientation codes by Kazimierz Obuchowski}

The cognitive account places orientation in the area of information receiving and processing mechanisms. On the one hand, the cognitive perspective is entirely obvious here, when we take into account that the object or subject of orientation performs the detection of stimulation. This, in turn, forms the basis for determining the reaction vector, even if it consists only in inducing readiness. On the other hand, the detection-reaction mechanism is involved in the system created by the subject and its surroundings, whose specificity consists in the flow and selection of information. This approach allows us to highlight the cybernetic nature of orientation. An advanced model taking into account the aspects of this issue which were mentioned above was proposed by Kazimierz Obuchowski $(1982,1985)$ in his theory of orientation codes.

The subject matter of Kazimierz Obuchowski's theory is subjective orientation in the surroundings, treated as a process in which the subjects situate 
themselves in the conditions imposed by their own dispositions and surroundings. This process consists in searching for and using changes in the surroundings as information carriers, informing the choice of how to obtain the optimal level of self-regulation (Obuchowski, 1982, p. 34). As Obuchowski notices, the maximization of orientation has contributed to the adaptive success of man, and a specifically human ability - language - has served as a catalyst in this process. This catalyzing role consists in the possibility of detaching from the present situation and a specific experience, providing the opportunity to prepare or choose the optimal option without having to try it beforehand (Obuchowski, 1982, p. 12). Indeed, words and syntax allow us to condense information and build complex models of objects, phenomena, events and processes. ${ }^{2}$ Owing to this, orientation may transcend the current physical situation and enable us to solve problems in a virtual way, without the need to operate on the material available in the physical experience.

One of the basic assumptions of Obuchowski's theory which he derives from the analysis of the theories and research of other authors, including Piaget and Pavlov, is the integrity of cognition and action processes (Obuchowski, 1982, pp. 17-21). Obuchowski argues that generally, the relationship between cognition and action should be treated as a single process in which both these elements intermingle in mutual cooperation. We can also realize this on the basis of the very nature of the orientation process, when looked at more thoroughly. During this process, registration and processing of information is linked to self-regulation, and thus to responding to the information and taking it into account while actively adapting to the circumstances. The sensory data trigger the process of internal information processing, at the same time allowing us to perceive functions of objects and as a result, activate executive procedures. The idea of the integrity of information processing and the activity implementation processes is justified by the theory of action (cf. Mądrzycki, 2002, pp. 69-81). In turn, Obuchowski's account of the cognition-action relationship corresponds to Gibson's ecological theory of perception (1986/2015) which is an expression of disagreement to separate these processes.

${ }^{2}$ Ludwig Wittgenstein (1922/2012) emphasized the role of language in modelling. With regard to the methodology of empirical research, it was pointed out by Roman Morawski (2011, p. 86) who recalled that creation of linguistic models (known as semantic models) and their mathematical counterparts is considered to be of fundamental importance for measurement and its theory (Morawski, 2011, pp. 85-92). In simpler terms, this issue boils down to the conceptualization of features and relations between them and their operationalization. 
According to Obuchowski, orientation is governed by two cooperating information organization systems: concrete and abstract. The concrete system is focused on detailed differentiation of information and extraction of fragments from the field formed by entire sets of external information (Obuchowski, 1982, p. 119). It organizes information on the basis of physical properties of the currently acting stimuli and delegates specific reactions through automated associations. Thus, the concrete system makes the orientation dependent on the current situation and its action has a vertical structure: the search for and organization of information goes from the receptors to the associative areas in the cerebral cortex (Obuchowski, 1982, pp. 59, 98). The abstract system in turn combines individual pieces of information separated by the concrete system with internal data existing in the form of a complex structure of concepts which forms mental representations of the world. In that way, it ensures emancipation from the current situation and extension of the repertoire of reactions based on previously accumulated experience. The structure of its operation is horizontal, which for Obuchowski means that the fundamental field of operations related to the search for and organization of information are brain areas constituting the substrate of the cognitive network that stores the content of categories. Both systems remain in a strict, though horizontal, relation, which means that they can operate relatively independently and that the organization of information is not a stacking process, which would first involve the concrete and then the abstract system. What is more, due to the action structure referred to above, the author defines as vertical orientation the one regulated by the concrete system, while the horizontal one is governed by the abstract system (Obuchowski, 1982, p. 101). Obuchowski provides numerous examples depicting the relationship between them (Obuchowski, 1982, pp. 42-105). In addition, each of the systems employs different information organization rules. Obuchowski calls these rules orientation codes. The concrete system operates on the basis of sensory data and conditioning mechanisms, while the basis for organizing information through the abstract system is formed by language. Admittedly, words can play a role in the concrete system, but this role consists mainly in sensory stimulation. A word can act as a sign of an object or a phenomenon, but the content of its meaning is skipped, and this content extends the repertoire of possible responses, providing a character to circumstances depending on the context in which the word will be used. The meaning of a word, which allows to situate it in the hierarchical structure of concepts determined by the relation of generality and subordination, is taken into account only in the abstract system (also called categorial, as it has at its disposal categories of varying degrees of generality). Only here appears the 
possibility of transcending the situational context, that is, of maximizing the orientation. This, in turn, according to Obuchowski, aims at the extra-linguistic information organization system going beyond the limitations of a linear language system, i.e. one based on sequences of concepts, where the meaning of each concept depends on the context that other concepts create. This higher orientation code of the abstract system is defined by the author as creative and identified by him with the operational language characterized by the maximization of the information-intensity of concepts and minimization of their ambiguity, and therefore a language of a high generalization level. The information is organized using this code in the form of simultaneous spatial operations often associated with iconic mental representations. An example here, according to the author, are scientific languages and those intended for solving theoretical problems and the specifics of scientific thinking, in particular those of its forms which relate to the so-called creative intuition and wordless manipulation (symbolic action) of ideas and on ideas (Obuchowski, 1982, pp. 207-208, 210-212; 1985, pp. 159-161). It is worth adding to the examples provided by the author yet another and very distinct one, related to the non-sentential concept of scientific theories. According to it, theories are families of semantic and iconic models of the fragments of reality to which they refer. The idea of an extra-linguistic system is an extremely interesting element in Obuchowski's theory of codes, which deserves to be discussed separately in the context of individual methodological orientations, but in another place.

Obuchowski points out that orientation is not just about exploring the surroundings. The latter is the function of the concrete system in which information travels from the receptors to the association areas in the cerebral cortex. The orientational success consists in getting insight into circumstances without reaching for external information (Obuchowski, 1982, pp. 97-98). Here, data circulate within the subject's knowledge structure. Activation of specific cognitive patterns triggers an avalanche of associations in the conceptual structure resulting in a multi-level mental representation. In comparison to the representation of the concrete system, this "abstract" representation expands response possibilities, permitting deviations from prototypes developed through the individual experience or allowing one to generate entirely new reactions and perform symbolic operations on it or using it.

According to Obuchowski, orientation does not consist in ever more accurate reflection of the situation either. The author notes that the purpose of orientation is to limit dependence on the current stream of information to which a person is subject (Obuchowski, 1982, p. 96). In this scope, the concrete 
system screens data and quenches reactions to impulses which are secondary from the point of view of efficiency, while the abstract system goes beyond the current situation by combining selected features with information stored in memory and experience gained from other contexts. Therefore, orientation is a process of information selection according to the rules (codes) ensuring an efficient situation in the stream of circumstances in which a person finds themselves. This manner of thinking about orientation is also confirmed by newer theories and studies of cognitive processes. The basic example in this respect is attention, which is treated as a mechanism responsible for reducing excess information, screening stimuli, directing other cognitive processes and allocating cognitive resources for the implementation of tasks (Eysenck \& Keane, 2002; Maruszewski, 2002; Nęcka, 2000). ${ }^{3}$

The dialectical unity of cognition and action visible in Obuchowski's theory of orientation codes translates into modelling of the methodological orientation as a complex feature combining cognitive operations with readiness to undertake specific activities. Therefore, contact with an object (stimulus) triggers not only a complex of cognitive patterns representing the properties of this object and a system of assumptions constituting it. At the same time, procedural rules underlying research activities are also activated.

Obuchowski's theory makes us realize the structural complexity of methodological orientation as a feature of the scientific mind. This complexity corresponds to the complexity of the structure of actions and activities undertaken in the research process. At the lowest level, orientation is based on the feed of sensory data that create multimodal complexes, which in turn determines (selects) the direction and nature of the activities. At the level of the abstract system, the dominant role is played by concepts and complex systems of mental representations that enable not only to map the complexity of the world, actions and procedures, but also to implement operations symbolically and generate new objects in the form of ideas.

In the light of Obuchowski's theory, the methodological orientation would consist in a complex mechanism of information processing and executing action programmes. The type and nature of information in the abstract sys-

${ }^{3}$ It should also be noted that in the context of attention, reference is made to the orientational reflex, understood as a mechanism of non-specific attention consisting in the spilling of stimulation in the neuronal system (Maruszewski, 2002, p. 82). It occurs in response to sudden stimuli, inconsistent or somehow standing out against the background of the stream of data. However, this strongly automated and biologically determined reaction remains within the scope of the concept of attention as a mechanism reducing the excess of information. 
tem would determine individual and group differences in the scope of methodological orientation. The abstract system would contain a hierarchical structure of concepts related to assumptions defining objectives of cognition, valid means and rules of information processing, or reasoning carried out on this information. These concepts and assumptions are acquired in the course of socializing experience taking place in the scientific environment.

To conceptualize methodological orientation, the issue of stabilization of the products of the concrete and abstract systems is also extremely important. Obuchowski's theory predicts that both these systems are equipped with mechanisms to secure created images and models of the world (Obuchowski, 1982, p. 138). The former stabilizes its products using learned associations, generalization mechanism and reaction quenching. The latter does so through systems of concepts in which models of reality and its fragments are recorded. This stabilization process consists mainly in skipping, downgrading or counteracting information that contradicts the individual's knowledge (cf. Obuchowski, 1982, pp. 131-138). In other words, such information causes a cognitive dissonance, and according to the theory by Leon Festinger, to which Obuchowski explicitly refers in his presentation of the problem of stabilization, information discrepancy evokes motivation to eliminate it. However, the tolerance threshold for this discrepancy remains a matter of individual differences. Hence, on the one hand, accepting ambiguity and remaining in a state of heterogeneous categorization is widely recognized as a token of psychological creativity. On the other hand, it evokes the category of ambivalence with all its theoretical background, and this allows one to develop the concept of methodological orientation and go beyond the framework of binary discrimination. It is an account that provides justification to the model of methodological orientation.

\section{c. Cognition-action duality in the theory of direct perception by James J. Gib- son}

Obuchowski's concept of orientation is based on the idea of the integrity of cognition and action processes. Above, the concept of affordance by James J. Gibson was mentioned. Due to the fact that it provides an inspiring background for the issue of the relationship between cognition and action, it seems right to devote more attention to it. At this point, it is worth pointing out an interesting circumstance: namely that Obuchowski published his theory 16 years ${ }^{4}$ before the release of the famous The ecological approach to visual perception by

\footnotetext{
${ }^{4}$ The first edition of Kody orientacji i struktura procesów emocjonalnych appeared in 1970.
} 
Gibson. In this publication, the basis of the direct knowledge theory is laid out. The ecological nature of Gibson's theory is expressed in viewing cognition in the context of environmental and subjective conditions in which it takes places. According to this theory, perception does not necessarily involve a categorizing mechanism using mental representations possessed by the subject, including cognitive patterns of objects, as presented in the theory of indirect knowledge. Quite the opposite, as the information that reaches the subject is contextual. A stimulus or feature is registered in the context of other data reaching the subject in the stream of perception. Gibson argues that the observer's surroundings are characterized by a certain order (ambient optical array) ${ }^{5}$ and the position of the observer determines the range of possible observations of objects arranged in the environment. Ecological thinking favors the observation that in fact the environment is a system of elements remaining in certain relationships. This results in the situation that perception of any of the elements of this environment depends on the context constituted by other elements and the position of the observer. Not only isolated features are perceived, but also structures connecting them, which results in the emergence the effect of seeing the surroundings as a configuration. This forms the basis of the idea of direct cognition, allowing it to be associated with the structuralist category of 'figure-ground' in Gestalt psychology (Maruszewski, 2002, p. 71). However, the variability of perception conditions permeates into and is permeated by the constancy of perceptions. In this context, Gibson uses the concept of invariants, which he defines as an arrangement of features that remain constant despite the changing conditions of perception (Gibson, 1986/2015, pp. 277-298).

In the process of perceiving an object, calibration takes place which takes into account changes of the object parameters and properties occurring in the perception field. This complex process is based precisely on invariants that secure the balance between variability and constancy of perception, thus ensuring the ability to identify objects despite changing conditions. In perceiving, however, according to Gibson, it is not the properties of the object which matter (Gibson, 1986/2015, p. 126). The object is perceived primarily because of the possibilities it creates for the observer, and - what is more - in the context of the needs and aspirations of the observer. Perceiving each feature individually, and then combining it with others into a conglomerate representing an object, would be non-adaptive and impractical from the perspective of environmental

${ }^{5}$ Gibson developed the theory of visual perception, though he clearly stressed the possibilities of extrapolating it onto perception in other sensory modalities (Gibson, 1986/2015, p. 298). 
conditions in which man as a species functions from the beginning of his phylogenesis and which are therefore invariant to him. ${ }^{6}$ This inadequacy of the representationalist approach is justified by Gibson by the principle of economics of perception and the specifics of the processing of information about objects in the surroundings by a child.

What attracts attention in objects determines the type or nature of the activity they afford. Thus, according to Gibson, not the isolated features of the object are perceived, but just the affordances. He defines them as an invariant combination of variables, which consists of specific skills or abilities of the subject and the possibilities provided by the characteristics of the surroundings to use these skills and abilities (Gibson, 1986/2015, p. 126). To paraphrase, affordances are all possibilities of action, including those perceived by the subject, allowed by the environment in which the subject is situated. This invariability, however, does not mean a total fixing of the link between a specific offer created by the object and the competence on the part of the subject. There is no clearly defined boundary between affordances. Moreover, they are consistent with each other and the same object can, in combination with the observer's capabilities, generate very diverse affordances (Gibson, 1986/2015, p. 126). The invariance of affordance consists rather in creating a range of invariant relationships between specific properties of the object and the possibilities of action that the observer sees in them. The affordance offer of the environment can be much wider than its actual use by the perceiving subject (Gibson, 1986/2015, p. 121). Therefore, it can be said that in the system created by a specific subject with a specific environmental system, certain affordances may not be updated. However, as part of a set, they remain relatively constant for the environmental niche of a particular person or group represented by him. Relatively, because the process of their formation and implementation is of emergent character, as it was indicated above.

It should be emphasized that according to Gibson, affordances cannot be reduced to the concept of mental representation. They remain opportunities in the sense of factors determining possible actions, behaviors, or functions to

${ }^{6}$ Gibson emphasizes (1986/2015, p. 122) that despite the assumption of the complementarity of the subject and the environment surrounding him, we should remember that historically, the environment preceded man as a species. The latter had developed in response to the conditions of this environment, constituting at the same time its result and an inseparable element. Therefore, it is not surprising that in his ecological theory of perception, Gibson employs the concept of an environmental niche, which in ecology describes the ways of functioning of representatives of specific species in the environments of their existence. Gibson suggests that in his theory of perception, a niche is the equivalent of a set of affordances (Gibson, 1986/2015, p. 120). 
be implemented, with the emphasis on the complementarity of the surroundings and the subject (cf. Gibson, 1986/2015, pp. 128-129). For Gibson, they constitute an interactive element of the environment in which there are many observers, but each of the latter perceives the possibilities provided by the environment differently (Gibson, 1986/2015, p. 129). This interactive, and sometimes even reciprocal, nature of perception becomes particularly visible in the case of such affordances, where the object of observation is another observer (human, animal) or their behavior (Gibson, 1986/2015, p. 127). What is more, the concept of affordance points out to the exploratory activity of the observer as a key factor in perception. The information not only reaches the observer, but the latter also actively seeks it, or matches it to the catalogue of his procedural dispositions. The emphasis of activity in Gibson's theory is transferred from the stimuli inflowing in the stream of data to passive receptors which are merely ready to register information, to the subject focused on picking up information (Gibson, 1986/2015, pp. 277-251). However, Gibson's ecological theory promotes the idea of bidirectional perception (Nęcka, Orzechowski, \& Szymura, 2006 , p. 312), i.e. the integration of the bottom-up (stimuli-based) and topdown (pattern-based) perception. Besides, affordances are related to the bottom-up semantic processing of information (Nęcka, Orzechowski, \& Szymura, 2006, p. 311), in this case the functions of perceived objects and the possibilities they afford in procedural terms. This property corresponds with the nature of the horizontal relationship between the concrete and the abstract system in the theory of orientation codes, forming thereby one of the clearest points of correspondence between Obuchowski's theory and Gibson's theory.

The elements of Gibson's theory presented so far can be implemented in the discussion on the concept of methodological orientations by referring mainly to the category of research practice. The latter consists of a set of specific actions, the implementation of which must be preceded by a recognition of the conditions and possibilities of selecting cognitive solutions offering an optimised level of effectiveness. Indeed, perception of any issues, including research problems, takes place in the context formed by these issues and the conditions that accompany them. The researcher, equipped with specific cognitive instruments, perceives issues, topics and phenomena through the possibilities of action they create for him. What the researcher, focusing on solving practical cognitive problems, perceives cannot be only properties of an object. This approach, consistent with the traditional concept of perception, provides a reduced picture of scientific cognition. The reduction consists mainly in losing the interactive nature of the relationship between the subject and the object 
of cognition, pushing the possibility of reconstruction of the process of scientific cognition into the field of active-passive, subject-object and cognitionaction dichotomies. Cognition, and scientific cognition in empirical sciences in particular, cannot be separated from action in a justified manner (Afeltowicz, 2012; Bauman, 2013; Latour, 2005/2010; Piekarski, 2010, 2013; Rubacha, 2017; Urbaniak-Zając, 2017). Indeed, perception of an object involves at the same time the evaluation of the possibilities that this object and its properties create for the cognising subject. It is not difficult to imagine that such research features as gender, sign of attitude, and learning speed are perceived in connection with programmes of activities that are allowed under certain conditions of research practice by these very features. In other words, the object of cognition, together with the context in which it occurs, is formed by an offer of possible research activities. Research perception is the perception of this offer. Therefore, representation of the object of cognition based on reflection of its properties is not characteristic of the process of scientific cognition. It is created secondarily, on the basis of affordances and triggered executive procedures that sample the object of cognition. Therefore, the function of the object and the subject remaining in relation to it will be an area of possibilities for action. According to this concept, it is this type of areas that are perceived, not objects as such. Of course, the language that participates in cognition will lead to the occurrence of the symptoms of hypostatizing in the process of perception, providing, for example, in the moments of introspective insight, the impression of constancy of the object and its features.

Therefore, the individual methodological orientation could be understood as an organization of information developed in disciplinary training, remaining in a relation to the multilevel structure of formed responses with various levels of generality and precision, and allowing to be referred to the system of affordances. The latter are understood as relations between dispositional properties of the environment and the subject (cf. Dotov, Nie, de Wit, 2012). The environment creates conditions for possible reactions and actions, and the subject demonstrates his or her specific readiness to perform actions to match these conditions. However, we are talking here about the duality of the environment and the subject, the duality in the form of a juxtaposition (Turvey, 1992) or, one could say - a product (result of multiplying), but in the sense that their specific (and not arbitrary) dispositions remain complementary, they imply and update each other. 


\section{A model of individual methodological orientations}

In accordance with the above observations and interpretations, the individual methodological orientation (IMO) is a complex interactive information organization process involving mechanisms related to perception, attention, memory and action. In its course, a categorization of stimuli takes place based on the subject's repertoire of mental representations (declarative knowledge). Therefore, it must be accompanied by perceptual readiness which consists in the availability of selected mental representations, making them easy to use in categorising stimuli and anticipating the referent of these categories. Along with the readiness of perception and categorization of stimuli, executive procedures are activated (procedural knowledge) - they are selected from the subject's repertoire accordingly to the possibilities that are created by the circumstances of the current situation. In this, the interactive nature of the individual methodological orientation shows itself.

Categorization and perceptual readiness create conditions for identification of individual methodological orientations. The manner in which information is organized shows itself to a certain degree in the observable selection, or favoring of some pieces of information over others. This allows to situate the subject in the field of methodological discourse. The longer the disciplinary training the subject underwent, the more interesting the situation becomes. However, it would be a mistake to expect that there is a simple relationship between the length of such training and the stabilisation and strength of individual methodological orientations (cf. Buczkowski, Klawiter, 1985; Klawiter, 1989).

Due to the fact that science is based on language, the environment of the activity of a scientist, or an adept of science, are mainly the conceptual systems of scientific disciplines. Reconstruction of the elements and structure of the methodological language of these disciplines promises to create a catalogue of signals-categories that can be used in assessing individual methodological orientations. Often the categories of methodological language occur in the systems of oppositions or antinomies, which results from the dichotomous thinking described above. The kind of thinking is reflected in the structure of the language of science and the organization of the reality described in this language (Hajduk, 2017; Malewski, 2017). It can be expected that this structure is internalized in the course of disciplinary socialization and used in organizing the information, whether it is limited to the mapping or pre-organization of data. Therefore, it is an attractive from the point of view of assessing the individual methodological orientation of representatives of the scientific field. Here, the catalogue of terms 
could form the basis for a set of observation instruments and for favoring information by these representatives.

Earl Babbie (2010, pp. 19-25) draws attention to the universality of the general characterization of research orientation in social sciences using three sets of such oppositions. These are: nomothetism vs. idiographism, deduction vs. induction, quantity vs. quality. The "versus" operator is not used here accidentally. Its meaning refers to the dynamics of tension expressed in the oscillations and stresses stabilizing the system (cf. Witkowski, 2015). It happens that these sets are presented separately, sometimes with an indication of relative correspondences (e.g. Cohen, Manion, Morison, 2007; Hajduk, 2011; Rost, 2008), although in fact it is possible to cross-reference them (see e.g. Babbie, 2010, p. 19; Pasikowski, 2017; Rost, 2008, pp. 23-25).

In principle, the opposing categories are classes. Within each of them there are sets of categories that have their opposition in the opposite class. A closer semantic analysis of these class-categories allows us to realise that they relate in general to the three elements of cognition taking place in the empirical social sciences. What is more, taking place in correspondence with the action factors described by psychological theories of this process (Mądrzycki, 2002). In the order corresponding to the above sequence of the three opposing pairs of categories, these factors will be: the aim of cognition, the pattern of reasoning and the ways of organizing the process of cognition.

\section{a. The aim of cognition (A)}

This distinction was introduced by Wilhelm Windelband (1900/1984; 1900/1998) who presented a formal principle of classifications of the aims of scientific cognition as a response to the confusion in classifying the procedure of investigation in empirical sciences (and not the content of knowledge) and at the same time as an expression of disagreement with the Diltheyan division. As empirical, Windelbrand defined those disciplines in which the premise of statements is experience or perceived data. These include both natural sciences and humanities. According to Windelband, scientific thinking is subject to a "methodological opposition" (1900/1984, p. 26; 1900/1998, p. 13). This is how he defines the differentiation of procedures of investigation determined by different aims of cognition. In contact with the observed event, cognition may be focused on treating this event as a manifestation of possible regularity or as a unique, specific and individual whole. In the first case, an isolated event is irrelevant to the construction of scientific knowledge, in the latter case - it is of fundamental importance. Windelband maintains that the nomothetic procedure is associated 
with the predominance of abstract thinking in creating the representation of events. In turn, in the idiographic procedure, there is a prevalence of representations formed mainly on the basis of perception, understood as the "individual vividness of individual reality". In consequence, these different aims of cognition and ways of thinking around events result in laws and generalizations transcending the events, or detailed descriptions and presentations formulated in relation to specific events. However, it is wrong to treat the procedures as mutually exclusive. Because, it is only when they are involved together, as Windelband emphasizes, they allow to explain the event. Indeed, all events can be recognized in the context of two types of causes: regularity and a specific condition occurring at a given time and place. Windelband and his student Heinrich Rickert (Rickert, 1984; Staiti, 2013) maintained that there was tension and oscillation between nomothetism and idiographism, and pointed out to the cooccurrence of both in the process of ever more complete cognition of examined objects. Owing to Rickert, the meaning of both concepts has evolved and they are now used in the division of sciences and scientific explanations, which has been justifiably criticized (Grobler, 2008, p. 250; Habermas, 1988, pp. 1-3; Giddens, 2001, p. 93). ${ }^{7}$ On the other hand, the effects of this evolution reveal the phenomenon of favoring of dichotomic classification strategies, which, while drawing clear boundaries, do this at the price of the reduction of subtler properties. The categories of "nomothetism" and "idiographism", in their original meaning emphasizing the relationship that connects them, seem to be useful in describing individual predilections to create knowledge and thinking about the examined objects in terms of more general regularities or individual, specific properties, in some sense unique and one-off.

\section{b. Pattern of reasoning $(R)$}

The intellectual aspect of scientific activity is expressed above all in reasoning. Reasoning is a form of thinking. The latter in turn is a cognitive process consisting of mental operations. Reasoning is therefore a cognitive process that transforms information, called a set of premises, so as to derive a conclusion from them (Galotti, 1989, citing: Maruszewski, 2002, p. 361). In essence, it is the

7 The non-exhaustive character of the distinction using the category of nomothetism and idiographism was pointed out by Kuroda Masasuke (1987), who proposed to supplement the division of sciences using these categories with the concept of idiomodific sciences. However, the analysis of his argumentation indicates a close proximity of the categories of idiomodific and idiographic sciences. It seems that the only strong argument for maintaining this distinction is referring to the criterion of change. 
thinking in which, from a proposition about the logical value of certain sentences (premises), a proposition is derived about the logical value of other sentences (conclusion) (Ajdukiewicz, 1975; Łukowski, 2012). In other words, it is the thinking as a result of which, from incomplete information, a result is derived that fills the gaps in knowledge. The reasoning is divided into simple and complex (Hajduk, 2011). In the group of simple reasoning there is deductive reasoning and inductive reasoning, also known as probabilistic, which are opposite to each other. On the other hand, explanation, proof and refutation are included in the group of complex reasoning. This division had proved to be insufficient. Currently, the reasoning is divided primarily into two classes: infallible (deductive) and fallible (reduction) (Lukowski, 2012) or deductive and nondeductive (Bunge, 1983, p. 199). From them, other types of reasoning are derived. Simple inductive reasoning belongs to the class of reductive reasoning, and simple deduction - to the class of deductive reasoning.

In the context of Charles Peirce's dichotomy of deductive and inductive reasoning, he distinguished abductive reasoning. However, a closer analysis shows that this reasoning, in its simplest one-stage form, has the features of the probable reasoning, namely the reductive one, in which out of a consequence (that is a premise) the reason is being derived (that is the conclusion) (Urbański, 2009). Most often, however, abductive reasoning occurs in the form of the complex reasoning with a dominant of deduction or reduction (Urbański, 2009).

The opposing deductive and inductive reasoning, despite the existing differences, remain in a relation of mutual complementation in the course of implementation of subsequent links of reasoning. The reasoning process, the object of which are the complex phenomena of the surrounding world, is characterized by a continuous movement and the occurrence of turns. It can proceed from the particular to the general, just to reverse this pattern within a moment. Thus, in the practice of reasoning, during one act, there may be processes that concurrently implement the pattern of induction and deduction. An apt expression of this idea is the concept of the research process as an interactive continuum (Newman, Benz, 1999). In the light of this concept, the advantage of one type of reasoning over the other is of a temporary nature, or even derives from the adopted definition of a more general purpose of the research: theory building vs. theory testing. Clear convergence can also be seen in the division, proposed in the idealizing theory of science (Nowak, 1977), into the stages of building scientific knowledge: the empirical-collecting stage, in which the inductive reasoning dominates, and the theoretical-explanatory stage, in which with idealising-concretising thinking is prevalent. Therefore, ultimately inductive 
and deductive types of reasoning co-exist and complement each other, resulting in a more complete cognition. In this manner, Mieczysław Malewski (1990, pp. 155-156) supports integration of the inductive and deductive building of knowledge and at the same time emphasizes the inevitability of combining these two perspectives along with the development of the scientific discipline.

It should be noted that in scientific thinking, a significant role is also played by another thinking act, usually contrasted with reasoning - intuition (Hajduk, 2011, p. 51; Wehler, 1998, pp. 50-51). Intuitive cognition is not essential in the process of building scientific knowledge, because the latter requires justification. However, scientific cognition does not exclude intuition in the research practice. Nevertheless, it requires that the effects of intuitive impulses are subject to rational justifications. What is more, the search for premises of existing statements often leads to discovering that intuition is at the heart of assumptions and positions. The intuition, however, usually turns out to be an automated cognitive process based on the subject's knowledge, semantic relationships and entailment, to which the subject has limited conscious access (Kolańczyk, 2009, 2011). It is also described as the holistic information processing carried out using deductive (!) procedures (Nosal, 1992, p. 18).

\section{c. Ways of organizing the process of cognition (M)}

Behind this concept, there are categories describing the conditions for collecting and analyzing data. In the methodology of empirical research they are expressed by means of terms of research strategies and schemes and data analysis methods and instruments, together with assumptions as regards the properties of cognition. The terms commonly used in describing and classifying these methods of organization of the research process are "qualitative research" and "quantitative research". These terms can be understood narrowly or broadly. In the first case, they define the strategy of data collection and analysis, which is sometimes called a "broad design type" (Hutchinson \& Lovell, 2004), in which the format of data plays a decisive role: they are either literal (verbal) or numerical. In the second case, they include complexes of different assumptions as to the nature and aspirations of empirical research (Bryman, 1988, p. 3; Niglas, 2010). The common denominator of qualitative approaches is supposed to be expressed in the phenomenological basis of the research aimed at discovering and reconstructing the meaning in the spirit of the verstehen category. In the case of quantitative approaches, their common denominator would be expressed in using statistical instruments, including the probability theory, and conducting research aimed at discovering statistical regularities in mass pro- 
cesses, which in the practical layer is expressed in the assessment of properties of data sets, and not single observations. The validity of the division based on the data format criterion is sometimes questioned by the representatives of statistics themselves (Steczkowski, Zeliaś, 1981, p. 17). The second approach in turn can be more precisely expressed using other concepts than those based on the opposition of quantity and quality (cf. Harris, 1976; Sułkowski, 2012). The division into qualitative and quantitative research is sometimes also accused of excessive simplification. The former are much more internally differentiated and sometimes more different in itself in the ontological and epistemological basis than compared to a specific form of quantitative research (Flick, 2008; Konecki, 2000; Niglas, 2010, p. 222; Urbaniak-Zając, 2011, 2006). Oftentimes, these types of research are identified and characterized by such dichotomies as nomothetism-idiographism and normativism-interpretivism (cf. Cohen, Manion, Morrison, 2007; Konecki, 2000; Rubacha, 2008). However, as it was already shown above, these distinctions are sometimes misleading as they do not take into account the presently accepted use of qualitative research to discover regularities and build a theory (cf. Flick, 20008; Urbaniak-Zając, 2006; Konecki, 2000; Silverman, 2015) and remain silent as to the question of the theorisation of observations, and therefore also the difficulty in making such idealizing divisions (e.g. Grobler, 2008, p. 250).

The division mentioned above is not supported in the image of science created by contemporary philosophy. One of the basic categories around which science is organized is truth (cf. Morawski, 2011). Despite the ambiguity and complex models describing this category, it is among the key issues for the investigations on science, including the reliability of cognition, which the researchers look for (cf. literature on the validity and reliability of measurement and research). Hence, the division into qualitative and quantitative research has a similar value to the division based on which cognition takes place either by reasoning or by experience. At present there is no doubt that both these processes are inextricably linked during the building and verification of knowledge. Likewise, sticking to the separation of what is quantitative and qualitative in the collection and analysis of any data, compels the perception of the data itself and the process of cognition in a way that limits them to a narrow set of their aspects. Meanwhile, from the perspective of the full image of the cognized phenomenon, the qualitative and quantitative data and methods complement each other, and their combined use is sometimes necessary (Glaser, Strauss, 2009, pp. 17-20). An expression of this position is the so-called paradigm of mixed methods research. 
What essentially facilitates thinking about the simplifying nature of the methodological "qualitative-quantitative" dichotomy is allowing for the possibility of existence of data collection and analysis methods relatively independent from the worldview of the researcher using them, individual epistemologies, and even relatively independent from the perspective of the continuum of methods (cf. Konecki, 2000). This way of thinking is supported by the idea of affordance and the rule of juxtaposition, whereby arbitrary resolution as to the location of methods becomes doubtful. Finally, in the context of the research division using the "qualitative-quantitative" dichotomy, it is worth recalling the position according to which the choice of the research approach is legitimately considered in the context of the researcher's psychological conditions (cf. Marshall, Cardon, Poddar, \& Fontenot, 2013, p. 12; Patton, 2002).

\section{d. Organization of information in the space of the ARM system}

In the model of individual methodological orientations, the elements of the cognition process outlined above can be characterized using opposing features, in such a way that these features would determine the field of possible forms of each of these elements. Therefore, the description of a methodological orientation can be based on at least the characteristics of each of the six features that constitute the three mentioned superior features forming together a system of individual information organization (ARM). The hierarchical structure of the semantic network allows us to distinguish the successive levels of methodological categories, which has significant implications for the operationalization of the individual methodological orientations. Demarcations, classifications aiming at unilateralization, and misunderstandings and conflicts occurring on the background of methodological identification may result from focusing on selected categories, reducing the described or evaluated solution or methodological approach to them, without taking into account the whole of the phenomenon. Such a reductive approach skips the properties that manifest themselves only when the whole picture is considered. The contradictions present in fragmentary insights may in fact be not opposing, but complementary aspects of unity, which I have tried to show above.

The proposed characteristics of methodological orientations reveal the problematic nature of isolated pure forms and unambiguous typologies. A multidimensional system based on sets of opposing categories shows different forms that can exist in the space defined by these oppositions. The phenomenon characterized in this way can be cognized taking into account its possible internal tensions and variability, e.g. depending on the time in which the development 
and formation of the scientific mind takes place. The condition for the above is the conceptualization of constituent features as continuum properties, the transition from typological approaches using absolute categories, towards modelling using the idea of grading in a unipolar continuum. This is justified in the work and research on features that are modelled in the structure of opposition (Cacioppo, Berntson, 1994; Cacioppo, Gardner, Berntson, 1997; Larsen, Norris, McGraw, Hawkley, Cacioppo, 2009; Rudolph, 2006). Owing to this, each of the three superior features modelled in this way would have its representation in the coordinate system. The result of the unification of these three systems is the isometric system (Figure 1), in which each of them corresponds to one of the three planes determined by separate pairs of axes. In turn, each of the axes in a pair represents a separate category, one of the two opposing ones. Marking values on neighbouring axes allows us to determine the coordinates of the point of intersection of lines running from these values. In this way, one quadrilateral is marked on each of the three planes. These three quadrilaterals together symbolise the individual space of information organization (IMO) along with the potential repertoire of individual dispositions possible to implement (based on juxtaposition) in the research process. In other words, the model illustrates a space in which the subject, symbolized in Figure 1 by the point, moves by

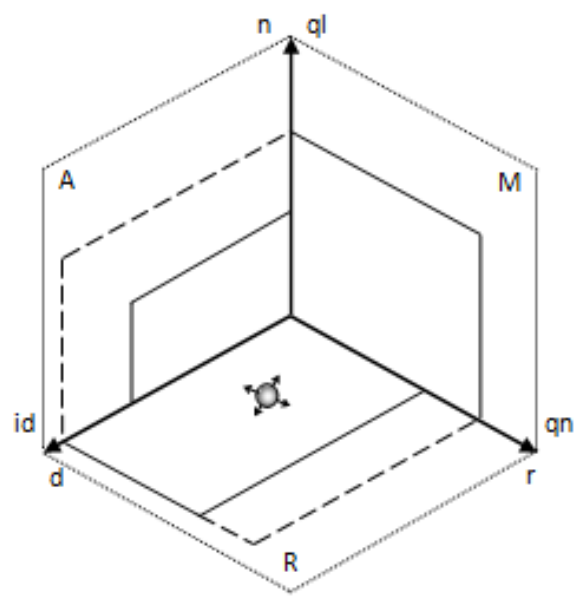

Figure 1. A model of individual methodological orientations (IMO) - organization of information in the space of the ARM system

A - aim of cognition, $\mathrm{R}$ - pattern of reasoning, $\mathrm{M}$ - methods/ways of organizing the process of cognition, id - idiographic, $n$ - nomothetic, $d$ - deductive, $r$ - reductive, $q$ - qualitative, qn - quantitative Source: Author's compilation. 
choosing the ways of organizing information from the repertoire of dispositions remaining in his range - dispositions in terms of aim, patterns of reasoning and ways of organizing the process of cognition. However, this repertoire cannot be understood as a function of previous experience but of juxtaposition, which means that apart from the ways of organizing acquired by the subject through learning, the subject also creates new ones in the current experience, which consists in compiling subjective and environmental disposition.

A special place in the model is occupied by the issue of relations between the opposing features. It expresses itself in tension, a property characteristic of the plane that forms the individual field of information organization. Tension is a function of two properties: the polarization of the components of the complex feature and their intensity. Although the idea of tension definitely remains in the range of the concept of ambivalence, I introduce it because of the broad meaning scope of the latter concept.

The tension model is expressed in the following formula:

$$
T=\left(\frac{\min (a, b)}{\max (a, b)}\right)\left(\frac{m_{a . b}}{\max _{s}}\right)
$$

$T$ - tension, $a$-intensity of the first feature, $b$-intensity of the second feature, $\min (a, b)$ - the lower of $a$ and $b$ values, $\max (a, b)$ - the higher of the $a$ and $b$ values, $m_{a, b}$ - the arithmetic mean of $a$ and $b$ values, and $\max$ - maximum value of the rating scale.

The first component on the right side of the equation is the polarization measure. The form of this quotient determines the portion of the intensity of the stronger feature constituted by the intensity of the weaker feature. It takes values from the range $[0,1]$. It is worth noting here that the stronger the polarization of the opposing features, the higher the value of this ratio.

In turn, the measure of intensity is the arithmetic mean of the values taken by the opposing features. Intensity takes values within the range predicted in advance by the model, i.e. [min, $\max$ ] of the rating scale used to measure both features. As in the case of polarization, the ratio of the arithmetic mean of measurements of the opposing features and the maximum value of the rating scale takes values in the range $[0,1]$.

The inclusion in the formula of the maximum value of the rating scale used in the measurement makes that the coefficient of tension assuming normalized values in the range $[0,1]$.

The presented algebraic formula is the result of the studies that I conducted over the features modelled in the structure of oppositions. The compo- 
nents which this formula includes are justified in the work and research of other authors (e.g. Kaplan, 1972; Priester, Petty, 1996; Thompson, Zanna, Griffin, 1995). However, its application requires that the opposing features are modelled using unipolar rather than bipolar continuums. Apart from the theoretical substantiation (Kaplan, 1972; Thompson \& Zanna, 1995; Thompson, Zanna, Griffin, 1995), methodological reasons also support this (Cacioppo, Gardner, Berntson, 1997; Pasikowski, 2018).

The tension that is the property of the relation of the opposing components of a complex feature is illustrated in the graphical image of the methodological orientation model (Figure 1). Polarization of categories representing a complex feature is expressed by the length of the sides of the quadrilateral. The smaller the difference between them, the stronger the polarization. In turn, the intensity of tension between the opposing categories is expressed in the size of the surface of the quadrilateral formed on the plane between the axes. The larger the surface area, the higher this intensity. The maximization of tension within each plane of the system should be interpreted as maximization of the repertoire of dispositions within this subject's reach in domain of information organization regarding to the aim of cognition, the reasoning model and the strategy of data collection and analysis. In turn, the balance of tensions expressed in the similarity of the size of quadrilaterals created in the system space could indicate a similar mechanism or process that the abovementioned category of orientation balancing introduced by Gnitecki describes.

The model also provides a description of the space outside the area of the individual methodological orientation (IMO). This space can be defined as the space of dispositions isolated in the system of individual information organization (ARM). It is no less an interesting area than IMO, as it connects with the question about the form of IMO and the scope of ARM, which IMO does not cover. Within the space of isolated dispositions, the proximal part and the distal part can be distinguished. The border between them is symbolized in Figure 1 by the dashed line.

The proximal part refers to the range of possibilities similar in terms of semantics and functionality to the repertoire covered by the IMO (in Figure 1 symbolized by a field extending from the quadrilateral to the dash line). In fact, it is about the differences between tensions in areas $\mathrm{A}, \mathrm{R}$ and $\mathrm{M}$. These areas constitute an integral whole, so differences between the tensions that characterize them can result from fixed associations and habits acquired in individual experience. For example, the development of repertoire in the field of instruments is sometimes limited to the selective aims of cognition, despite wider 
possibilities offered by acquired tools and skills. Similarly, the potential of any individual dispositions and those dispositions offered by the environment of acting may be limited by well-established beliefs about their possible applications and usefulness. In each of these cases, initiation and maintenance of processes such as functional fixation takes place. Its reduction seems easier than developing new dispositions.

The distal part of the space of isolated dispositions (in Figure 1 symbolized by the field from the dashed line to the edge of the ARM system) includes those dispositions that require the development of more advanced relationships and associations, hence the chances that the subject will use some of them seem to be much smaller.

The issue of the space of isolated dispositions would have consequences for the planning of activities developing individual methodological orientations. The effectiveness of these activities could be higher if they were focused on dispositions that can be linked or associated with the dispositions already possessed.

Each of the elements described and illustrated in Figure 1 is expressed in the form of algebraic formulas, which are presented below. The basis for these formulas is the coefficient of tension (T).

The individual methodological orientation (IMO) can be presented as the product of tensions $(\mathrm{T})$ in the planes forming an integral whole: the aim of cognition (A), the pattern of reasoning (R) and ways of organizing the process of cognition (M).

$$
I M O=T_{A} \cdot T_{R} \cdot T_{M}
$$

The space of isolated dispositions, briefly "isolated space" (IS), in the system of individual information organization is the difference between the maximized scope of the information organization space and IMO.

$$
I S=1-I M O
$$

The proximal space of isolated dispositions $\left(\mathrm{IS}_{\mathrm{prox}}\right)$ is the difference between the balanced scope of the information organization space (expressed as the highest of the tension coefficient raised to the third power: $\left.\mathrm{T}_{\max }^{3}\right)$ and IMO.

$$
I S_{p r o x}=T_{\max (A, R, M)}^{3}-I M O
$$


In turn, the distal space of isolated dispositions $\left(\mathrm{IS}_{\text {dist }}\right)$ is expressed by the difference between the maximized scope of the information organization space and the balanced scope of the information organization space.

$$
I S_{\text {dist }}=1-T_{\max (A, R, M)}^{3}
$$

The presented algebraic formulas constitute the content of the model of individual methodological orientations, allowing us, first of all, to approximate the theory. However, they can be useful in describing and assessing the phenomenon based on empirical data obtained through measurements.

\section{Conclusion}

The presented model is an approximation of the issue of individual methodological orientations. It is based on the assumption of dichotomization in the language of the methodology of science and employs the theoretical potential of the ambivalence concept. The understanding of methodological orientations in terms of theoretical assumptions or information filters reduces this concept, losing the essential element of the subject's sphere of activity. Hence, when conceptualizing the methodological orientation, it is essential to integrate the processes of cognition and action more so that their interaction is expressed in the research practice and the process of undertaking particular scientific activities. The nature and form of this practice and activities are conditioned by socialization factors, among which disciplinary training and methodological education seem to play a fundamental role shaping certain methodological niches and developing predilections to occupy them. These, in turn, can be expressed in individual methodological orientations. With the help of the presented model, it becomes possible to display graphically the profiles of differentiation in the area of individual methodological orientations. This creates the opportunity to see mutual connections and tensions, properties (which are usually accounted for in a fragmentary and isolated manner) conceptualized in the methodology of science and to show the possibility of their interaction and even compatible functioning, despite defining such a situation in terms of oppositions or antinomies. After the operationalization process, the model could become part of the offer to create background for the needs of the development of research competences and the improvement of the education process in the field of empirical research methodology . 


\section{References}

Afeltowicz, Ł. (2012). Modele, artefakty, kolektywy. Toruń: Wydawnictwo Naukowe UMK.

Ajdukiewicz, K. (1975). Logika praktyczna. Warszawa: PWN.

Babbie, E. (2010). The Practice of Social Research. Belmont: Wadsworth, Cengage Learning.

Bachelard, G. (2000). Filozofia, która mówi nie. Esej o filozofii nowego ducha w nauce. Gdańsk: słowo/obraz terytoria.

Badach, K., Smyk, K. (2016). Opozycje jako kategorie kulturowe. Lublin: Wydawnictwo Uniwersytetu Marii Curie-Skłodowskiej.

Banaszak, S. (2017). Teoria i empiria - kilka uwag metodologicznyh i praktycznych. In: D. Kubinowski, M. Chutorański (eds.), Pedgogika jako humanistyczno-społeczna nauka stosowana: konsekwencje metodologiczne (pp. 83-93). Kraków: Impuls.

Barrows, E. M. (2011). Animal BehaviorDesk Reference. A Dictionary of Animal Behavior. Boca Raton, London, New York: CRS Press.

Bateson, G. (1996). Umyst i przyroda. Jedność konieczna. Warszawa: Państwowy Instytut Wydawniczy.

Bauman, T. (2013). Kompetencje badawcze a świadomość metodologiczna. In: T. Bauman (ed.), Praktyka badań pedagogicznych (pp. 81-98). Kraków: Impuls.

Biedrzycki, M. (1998). Genetyka kultury. Warszawa: Prószyński i S-ka.

Bilikiewicz, A. (2000). Psychiatria. Podręcznik dla studentów medycyny. Warszawa: Wydawnictwo Lekarskie PZWL.

Błaszak, M. (2013). Ekotypy poznawcze człowieka. Przyczynek do kognitywistycznej teorii podmiotu. Poznań: Bogucki Wydawnictwo Naukowe.

Bolin, B. L., Lee, K. H., GlenMaye, L. F., Yoon, D. P. (2012). Impact of Research Orientation on Attitudes Toward Research of Social Work Students. Journal of Social Work Education, 48(2), pp. 223-243.

Bonner, A., Sando, J. (2008). Examining the knowledge, attitude and use of research by nurses. Journal of Nursing Management, 16, pp. 334-343.

Braun, M., Hemmersbach, R. (2008). In: S. Gilroy, P. H. Masson, Plant Tropism (pp. 141-160). Ames, Oxford, Carlton: Blackwell Publishing.

Brown, D. E. (2004). Human Universals, Human Nature, Human Culture. Daedalus, 133 (4), pp. 47-54. 
Bryman, A. (1988). Quantity and Quality in Social Research. London, New York: Routledge.

Brzeziński, J. (1978). Metodologiczne i psychologiczne wyznaczniki procesu badawczego w psychologii. Poznań: Wydawnictwo Naukowe UAM.

Buczkowski, P., Klawiter, A. (1985). Rekonstrukcje, interpretacje, rozwinięcia. Przedmowa (Poznańskie Studa z Filozofii Nauki, 9). In: P. Buczkowski, A. Klawiter (eds.). Warszawa-Poznań: PWN.

Bunge, M. (1983). Treatise on Basic Philosophy. Volume 5. Dordrecht, Boston, Lancaster: D. Reidel Publishing Company.

Cacioppo, J. T., Berntson, G. G. (1994). Relationship between attitudes and evaluative space: A critical review, with emphasis on the separability of positive and negative substrates. Psychological Bulletin, 115(3), pp. 401-423.

Cacioppo, J., Gardner, W., Berntson, G. (1997). Beyond Bipolar Conceptualizations and Measures: The Case of Attitudes and Evaluative Space. Personality and Social Psychology Review, 1(1), pp. 3-25.

Chojnicki, Z. (2000). Filozofia nauki. Orientacje, koncepcje, krytyki. Poznań: Bogucki Wydawnictwo Naukowe.

Cohen, L., Manion, L., Morison, K. (2007). Research Method in Education. 6th Edition. London, New York: Routledge.

Creswell, J. W. (2014). Research Design. Qualitative, Quantitative and Mixed Method Approaches. Los Angeles, London: SAGE Publications.

Desimpelaere, P., Sulas, F., Duriez, B., Hutsebaut, D. (1999). Psycho-epistemological styles and religious beliefs. International Journal for the Psychology of Religion, 9(2), pp. 125-137.

Dotov, D. G., Nie, L., de Wit, M. M. (2012). Zrozumieć afordancje: przegląd badań nad główną tezą Jamesa J. Gibsona. Avant, 3(2), pp. 282-295.

Dusenbery, D. B. (2009). Living at Micro Scale: The Unexpected Physics of Being Small. Cambridge, London: Harvard University Press.

Eysenck, M. W., Keane, M. T. (2002). Attention and Performance Limitations. In: J. D. Levitin (ed.), Foundations Of Cognitive Psychology (pp. 363-398). Cambridge, London: The MIT Press.

Filmer, P., Jenks, C., Seale, C. (2010). Developments in social theory. In: C. Seale (ed.), Researching Society and Culture (pp. 33-46). London: Sage Publications.

Flakus, M. (2017). Znaczenie postaw wobec badań naukowych i statystyki w procesie kształcenia akademickiego psychologów. Przegląd literatury. Edukacja, 4(143), pp. 76-89. 
Flick, U. (2008). Managing Quality in Qualitative Research. Los Angeles, London, New Delhi, Singapore: SAGE Publications.

Flick, U. (2009). An Introduction to Qualitative Research. London, Thousand Oaks, New Delhi: SAGE Publications.

Flick, U. (2011). Jakość w badaniach jakościowych. Warszawa: PWN.

Gibson, J. (1986/2015). The Ecological Approach to Visual Perception. New York, East Sussex: Taylor \& Francis.

Giddens, A. (2001). Nowe zasady metody socjologicznej. Kraków: Zakład Wydawniczy "NOMOS".

Gilroy, S., Masson, P. H. (2008). Preface. In: S. Gilroy, P. H. Masson (eds.), Plant Tropisms (pp. xiii-xv). Ames, Oxford, Carlton: Blackwell Publishing.

Glaser, B.G., Strauss, A.L. (2009). Odkrywanie teorii ugruntowanej. Strategie badania jakościowego. Kraków: Zakład Wydawniczy NOMOS.

Gnitecki, J. (1998). Zasada ambiwalencji zrównowazonej i zasda spójności w filozofii, nauce i edukacji. Poznań: Wydawnictwo Naukowe Polskiego Wydawnictwa Pedagogicznego.

Gnitecki, J. (2002). Filozofia nauki i edukacji. W okresie nowoczesności i ponowoczesności. Poznań: Wydawnictwo Naukowe PTP, Oddz. w Poznaniu.

Gnitecki, J. (2006a). Orientacje metodologiczne we współczesnej pedagogice. In: D. Kubinowski, M. Nowak (eds.), Metodologia pedagogiki zorientowanej humanistycznie (pp. 29-74). Kraków: Impuls.

Gnitecki, J. (2006b). Wstęp do ogólnej metodologii badań w naukach pedagogicznych (Tom 1). Poznań: Wydawnictwo Naukowe UAM.

Godoń, R. (2012). Między myśleniem a działanie. O ewolucji anglosaskiej filozofii. Warszawa: Wydawnictwo Uniwersytetu Warszawskiego.

Grobler, A. (2008). Metodologia nauk. Kraków: Aureus, Znak.

Groth-Marnat, G. (2003). The Handbook of Psychological Assessment. Hoboken: John Wiley and Sons.

Grzelak, J.Ł., Jarymowicz, M. (2000). Tożsamość i współzależność. In: J. Strelau (ed.), Psychologia. Podręcznik akademicki (Tom 3, pp. 107-146). Gdańsk: GWP.

Guba, E.G., Lincoln, Y.S. (2005). Paradigmatic controversies, contradictions, and emerging confluences. In: N.K. Denzin, Y.S. Lincoln (eds.), The Sage handbook of qualitative research (pp. 191-215). Thousand Oaks, CA: Sage.

Habermas, J. (1988). On the Logic of the Social Science. Cambridge, Massachusetts: The MIT Press.

Hajduk, Z. (2011). Ogólna metodologia nauk. Lublin: Wydawnictwo KUL. 
Hajduk, Z. (2017). Struktury metodologiczne w nauce. Lublin: Wydawnictwo KUL.

Harris. (1976). History and Significance of the Emic/Etic Distinction. Annual Review of Anthropology, 5, pp. 329-350.

Hutchinson, S.R., Lovell, C.D. (2004). A Review of Methodological Characteristics of Research Published in Key Journals in Higher Education: Implications for Graduate Research Training. Research in Higher Education, 45(4), pp. 382-403.

Jaroszyński, J. (1987). Zespoły zaburzeń psychicznych. In: S. Dąbrowski, J. Jaroszyńksi, S. Pużyński (eds.), Psychiatria, Tom 1, (pp. 20-41). Warszawa: PZWL.

Juszczyk, S. (2013). Badania jakościowe w naukach społecznych. Szkice metodologiczne. Katowice: Wydawnictwo Uniwersytetu Śląskiego.

Kamiński, S. (1992). Nauka i metoda. Pojęcie nauki i klasyfikacja nauk. Lublin: Towarzystwo Naukowe KUL.

Kaplan, K. J. (1972). On the ambivalence-indifference problem in attitude theory and measurement: A suggested modification of the semantic differential technique. Psychological Review, 77, pp. 361-372.

Kielar-Turska, M. (2000). Rozwój człowieka w pełnym cyklu życia. In: J. Strelau (ed.), Psychologia. Podręcznik akademicki (pp. 285-332). Gdańsk: GWP.

Klawiter, A. (1989). Trzy postawy wobec nauki - uczestnik, rozumiejący obserwator, badacz. In: J. Brzeziński, K. Łastowski (eds.), Filozoficzne i metodologiczne podstawy teorii naukowych (Poznańskie Studia z Filozofii Nauk, 11) (pp. 11-28). Warszawa-Poznań: PWN.

Knyazheva, I. A. (2012). Methodological Culture as a Socio-Cultural Phenomenon. Journal Education and Pedagogical Science, 3(152) pp. 33-37.

Kolańczyk, A. (2009). Trójczynnikowy model intuicji twórczej. Niejawna samokontrola, uwaga. W J. Kozielecki, Nowe idee w psychologii (pp. 40-65). Gdańsk: GWP.

Kolańczyk, A. (2011). Uwaga ekstensywna. Model ekstensywności vs. intensywności uwagi. Studia Psychologiczne, 49(3), pp. 7-27.

Konecki, K. (2000). Studia z metodologii badań jakościowych. Teoria ugruntowana. Warszawa: PWN.

Kubinowski, D. (2017). Badania pedagogiczne w kalejdoskopie paradygmatów, orientacji, podejść, metod nauk humanistycznych, społecznych i stosowanych. In: D. Kubinowski, M. Chutorański (eds.), Pedagogika jako humnistyczno-społęczna nuka stosowana: konsekwencje metodologiczne (pp. 15-24). Kraków: Impuls.

Larsen, J. T., Norris, C., McGraw, A. P., Hawkley, L. C., Cacioppo, J. T. (2009). The Evalu- 
ative Space Grid: A Single-Item Measure of Positivity and Negativity. Cognition and Emotion, 23, pp. 453-480.

Latour, B. (2005/2010). Splatajac na nowo, to co społeczne. Wprowadzenie do teorii aktora-sieci. Kraków: Universitas.

Levi-Strauss, C. (2011). Antropologia strukturalna. Warszawa: Aletheia.

Łukowski, P. (2012). Logika praktyczna z elementami wiedzy o manipulacji. Warszawa: Wolters Kluwer.

Malewski, M. (1990). Andragogika w perspektywie metodologicznej. Wrocław: Wydawnictwo Uniwersytetu Wrocławskiego.

Malewski, M. (2017). Badania jakościowe w metodologicznej pułapce scjentyzmu. Teraźniejszośc-Człowiek-Edukacja, 20, 2(78), pp. 129-136.

Marshall, B., Cardon, P., Poddar, A., Fontenot, R. (2013). Does sample size matter in qualitative research?: A review of qualitative interviews in is research. Journal of Computer Information System, 54 (1), pp. 11-22.

Maruszewski, T. (2002). Psychologia poznania. Gdańsk: GWP.

Masasuke, K. (1987). Trzy typy nauk: nomotetyczne, idiograficzne oraz „idiomodyficzne”. Colloquia Communia, 1-2/30-31, pp. 33-35.

Mądrzycki, T. (2002). Osobowość jako system tworzący i realizujący plany. Gdańsk: Wydawnictwo Uniwersytetu Gdańskiego.

Mitterer, J. (1996). Tamta strona filozofii. Przeciwko dualistycznej zasadzie poznania. Warszawa: Oficyna Naukowa.

Mitterer, J. (2004). Ucieczka z dowolności. Warszawa: Oficyna Naukowa.

Morawski, R. Z. (2011). Etyczne aspekty działalności badawczej w naukach empirycznych. Warszawa: Wydawnictwa Uniwersytetu Warszawskiego.

Mudyń, K. (2007). W poszukiwaniu prywatnych orientacji ontologicznych. Kraków: Wydawnictwo Uniwersytetu Jagiellońskiego.

Murphy, R. O., Ackermann, K. A., Handgraaf, M. J. (2011). Measuring Social Value Orientation. Judgment and Decision Making, 6(8), pp. 771-781.

Newman, I., Benz, C. (1999). Qualitative-quantitative Research Methodology: Exploring the Interactive Continuum. Carbondale, Edwardsville: Southern Illinois University Press.

Nęcka, E. (2000). Procesy uwagi. In: J. Strelau (ed.), Psychologia. Podręcznik Akademicki (pp. 77-96). Gdańsk: GWP.

Nęcka, E., Orzechowski, J., Szymura, B. (2006). Psychologia poznawcza. Warszawa: PWN, Academica SWPS. 
Niglas, K. (2010). The multidimensional model of research methodology: An integrated set of continua. In: A. Tashakkori, C. Teddlie (eds.), Mixed methods in social and behavioral research (pp. 215-236). Thousand Oaks, London: Sage.

Nosal, C. S. (1986). Indywidualne style poznawcze a preferencje metodologiczne badaczy. Zagadnienie Naukoznawstwa, 4 (88), pp. 627-644.

Nosal, C. S. (1992). Diagnoza typów umystu. Warszawa: PWN.

Nowak, L. (1977). Wstęp do idealizacyjnej teorii nauki. Warszawa: PWN.

Obuchowski, K. (1982). Kody orientacji i struktura procesów emocjonalnych. Warszawa: PWN.

Obuchowski, K. (1985). Adaptacja twórcza. Warszawa: Książka i Wiedza.

Palka, S. (1998a). Metodologiczne aspekty uprawiania pedagogiki. In: S. Palka (ed.), Orientacje w metodologii badań pedagogicznych (pp. 9-14). Kraków: Wydawnictwo UJ.

Palka, S. (1998b). Wstęp. In: S. Palka (ed.), Orientacje w metodologii badań pedagogicznych (p. 7). Kraków: Wydawnictwo UJ.

Palka, S. (2018). Wiązanie podejśc metodologicznych w pedagogice teoretyczno-praktycznej. Kraków: Impuls.

Papanastasiou, E. C. (2005). Factor Structure of the Attitude Toward Research Scale. Statistics Education Research Journal, 4(1), pp. 16-26.

Pasikowski, S. (2014). Kultura metodologiczna i raportowanie badań empirycznych publikowanych w wiodących czasopismach poświęconych zagadnieniom edukacji. Kultura i Edukacja, 2, pp. 103-133.

Pasikowski, S. (2016). Blitzkrieg i (re)kapitulacja w drodze do Twierdzy. Poza wizję radykalnych ataków i reaktywnych obron w budowaniu wiarygodnej wiedzy. In: M. Dudzikowa, S. Jaskulska, Twierdza. Szkoła $w$ metaforze militarnej. Co $w$ zamian? (pp. 182-202). Warszawa: Wolters Kluwer SA.

Pasikowski, S. (2017). Między swoistością a uniwersalnością w metodologii badań pedagogicznych. In: D. Kubinowski, M. Chutorański (eds.), Pedagogika jako humanistyczno-spoteczna nauka stosowana: konsekwencje metodologiczne (pp. 69-82). Kraków: Impuls.

Pasikowski, S. (2018). The Problem of Matching Rating Scales in Educational Measurement of Variables Modelled as Sets of Oppositional Pairs. The New Educational Review, 54(4), pp. 271-284.

Patton, M. Q. (2002). Qualitative Research \& Evaluation Methods. Thousand Oaks, CA: Sage.

Peachey, A. A., Baller, S., Schubert, C. (2018). Improvements in Research Orientation and 
Reductions in Barriers to Research Utilization among Undergraduate Students in Health Sciences. The Internet Journal of Allied Health Sciences and Practice, 16(2), p. 7.

Piekarski, J. (2010). Kryteria waloryzacji praktyki badawczej - między inhibicją metodologiczną a permisywnym tolerantyzmem. In: J. Piekarski, D. Urbaniak-Zając, K. Szmidt (eds.), Metodologiczne problemy tworzenia wiedzy w pedagogice. Oblicza akademickiej praktyki (pp. 151-174). Kraków: Impuls.

Piekarski, J. (2013). Badawcza praktyka i jakość wiedzy - wybrane uwarunkowania. In: T. Bauman (ed.), Praktyka badań pedagogicznych (pp. 13-34). Kraków: Impuls.

Pilch, T., Bauman, T. (2010). Zasady badań pedagogicznych. Strategie ilościowe i jakościowe. Warszawa: Wydawnictwo Akademickie „Żak”.

Pinker, S. (2005). Tabula rasa. Spory o naturę ludzką. Gdańsk: GWP.

Plante, T. G. (2005). Contemporary Clinical Psychology. Hoboken: John Wiley \& Sons.

Povee, K., Roberts, L. D. (2014). Qualitative research in psychology: Attitudes of psychology students and academic staff. Australian Journal of Social Research Methodology, 66 , pp. 28-37.

Povee, K., Roberts, L. D. (2015). Attitudes toward mixed methods research in psychology: the best of both worlds? International Journal of Social Research Methodology, 18(1), pp. 41-57.

Priester, J. R., Petty, R. E. (1996). The Gradual Threshold Model of Ambivalence: Relating the Positive and Negative Bases of Attitudes to Subjective Ambivalence. Journal of Personality and Social Psychology, 71 (3), pp. 431-449.

Reykowski, J. (1990). Ukryte założenia normatywne jako osiowy składnik mentalności. In: J. Rejkowski, K. Skarżyńska (eds.), M. Ziółkowski, Orientacje społeczne jako element mentalności (pp. 1-11). Poznań: Wydawnictwo Nakom.

Reykowski, J. (2000). Psychologia polityczna. In: J. Strelau (ed.), Psychologia. Podręcznik akademicki (pp. 379-404). Gdańsk: GWP.

Rickert, H. (1984). Obiektywność historii kultury. In: B. K. Borowicz-Sierocka (ed.), Neokantyzm (pp. 55-70). Wrocław: Wydawnictwo Uniwersytetu Wrocławskiego.

Ritter, S. E. (2012). Methodological Orientation of Research Articles (Tomy Theses, Dissertations and Capstones. Paper 211). Huntington, WV: Marshall University Marshall Digital Scholar.

Rost, J. (2008). Analiza danych empirycznych: aktualne pytania i rozwiązania. In: R. Stachowski, W. Zeidler (eds.), Opisowa metodologia badań psychologicznych. Studia i przykłady (pp. 12-26). Warszawa: Vizja Press \& IT. 
Royce, J., Mos, L. (1980). Manual: Psycho-Epistemological Profile. Center for Advanced Study in Theoretical Psychology, The University of Alberta.

Rubacha, K. (2008). Metodologia badań nad edukacją. Warszawa: Wydawnictwa Akademickie i Profesjonalne.

Rubacha, K. (2017). Interpretacja wyników badania jako kryterium analizy procesu badawczego. In: M. Dudzikowa, S. Juszczyk (eds.), Pułapki epistemologiczne i metodologiczne w badaniach nad edukacją (pp. 137-147). Katowice: Wydawnictwo Uniwersytetu Śląskiego.

Rudolph, L. (2006). Spaces of ambivalence: Qualitative mathematics in the modelling of complex fluid phenomena. Estudios de Psicologia/Studies in Psychology, 27 (1), pp. 67-83.

Rydlewski, M. (2016). Opozycja jako kategoria kulturowa w persepktywie poznańskeij szkoły kulturoznawczej. Opozycja jako wynalazek i element gramatyki europejskiej. In: M. Badach, K. Smyk (eds.), Opozycje jako kategoria kulturowa (pp. 23-34). Lublin: Wydawnictwo Uniwersytetu Marii Curie-Skłodowskiej.

Schraw, G. (2013). Conceptual Integration and Measurement of Epistemological and Ontological Beliefs in Educational Research. ISRN Education, pp. 1-19.

Sęk, H. (2001). Wprowadzenie do pscyhologii klinicznej. Warszawa: Scholar.

Sheehan, M. D., Johnson, R. B. (2012). Philosophical and methodological beliefs of instructional design faculty and professionals. Educational Technology Research and Development, 60(1), pp. 131-153.

Silverman, D. (2015). Interpreting qualitative data. Los Angeles, London: SAGE Publications.

Sojak, R. (2004). Paradoks antropologiczny. Socjologia wiedzy jako perspektywa ogólnej teorii społeczeństwa. Wrocław: Wydawnictwo Uniwersytetu Wrocławskiego.

Spendel, Z. (2005). Metodologia badań psychologicznych jako forma świadomości historycznej. Katowice: Wydawnictwo UŚ.

Staiti, A. (2013). Heinrich Rickert. In: E.N.Zalta, U.Nodelman, C.Allen (eds.) Stanford Encyclopedia of Philosophy. Stanford: The Metaphysic Research Lab, Center for the Study of Language and Information. Retrived 10, January from https://plato.stanford.edu.

Steczkowski, J., Zeliaś, A. (1981). Statystyczne metody analizy cech jakościowych. Warszawa: PWN.

Stomma, L. (2002). Tablice Mendelejewa. In: L. Stomma (ed.), Antrologia kultury wsi polskiej XIX wieku oraz wybrane eseje (pp. 185-236). Łódź: Piotr Dopierała.

Sułkowski, Ł. (2012). Metodologie emic i etic w badaniach kultury w zarządzaniu. Management and Business Administration. Central Europe, 1 (108), pp. 64-71.

Thompson, M. M., Zanna, M. P. (1995). The Conflicted Individual:Personality-Based and 
Domain-Specific Antecedents of Ambivalent Social Attitudes. Journal of Personality, 63(2), 260-288.

Thompson, M. M., Zanna, M. P., Griffin, D. W. (1995). Let's Not Be Indifferent About (Attitudinal) Ambivalence. In: R. E. Petty, J. A. Krosnick (eds.), Attitude strength: Antecedents and consequences (pp. 361-386). Hillsdale, NJ: Lawrence Erlbaum.

Turvey, M. T. (1992). Affordances and Prospective Control: An Outline of the Ontology. Ecological Psychology, 4 (3), pp. 173-187.

Urbaniak-Zając, D. (2006). W poszukiwaniu kryteriów oceny badań jakościowych. In: D. Kubinowski, M. Nowak (eds.), Metodologia pedagogiki zorientowanej humanistycznie (pp. 209-222). Kraków: Oficyna Wydawnicza "Impuls".

Urbaniak-Zając, D. (2011). Badania jakościowe jako źródło (naukowej) wiedzy pedagogicznej. In: T. Hejnicka-Bezwińska (ed.), Pedagogika ogólna. Dyskurs o statusie naukowym i dydaktycznym (pp. 93-109). Bydgoszcz: Wydawnictwo Uniwersytetu Kazimierza Wielkiego.

Urbaniak-Zając, D. (2013). Jakościowa orientacja w badaniach pedagogicznych. In: D. Urbaniak-Zając, E. Kos (eds.), Badania jakościowe w pedagogice (pp. 19-90). Warszawa: PWN.

Urbaniak-Zając, D. (2017). Proces badawczy jako podejmowanie decyzji - refleksja metodologiczna. In: D. Kubinowski,M. Chutorański (eds.), Pedagogika jako humanistyczno-społęczna nauka stosowana: konsekewncje metodologiczne (pp.181-195). Kraków: Impuls.

Urbaniak-Zając, D., Piekarski, J. (2003). Badania jakościowe - uwagi wprowadzające. In: D. Urbaniak-Zając, J. Piekarski (eds.), Jakościowe orientacje w badaniach pedagogicznych. Studia i materiały (pp. 13-31). Łódź: Wydawnictwo Uniwersytetu Łódzkiego.

Urbański, M. (2009). Rozumowania abdukcyjne. Modele i procedury. Poznań: Wydawnictwo Naukowe UAM.

Van Lange, P. A., De Bruin, E. M., Otten, W., Joireman, J. A. (1997). Development of Prosocial, Individualistic, and Competitive Orientations: Theory and Preliminary Evidence. Journal nf Personality and Social Psychology, 73(4), pp. 733-746.

Wehler, J. (1998). Zarys racjonalnego obrazu świata. Warszawa: Oficyna naukowa.

Wilden, A. (1980). System and Structure. Essays in Communication and Exchange. New York: Tavistock Publication.

Windelband, W. (1900/1984). Historia a przyrodoznawstwo. In: B. K. Borowicz-Sierocka (ed.), Neokantyzm (pp. 15-44). Wrocław: Wydawnictwo Uniwersytetu Wrocławskiego. 
Windelband, W. (1900/1998). History and Natural Science. Theory \& Psychology, 8(1), pp. 5-22.

Witkowski, L. (2013). Przełom dwoistości w pedagogice polskiej. Historia, teoria, krytyka. Kraków: Impuls.

Witkowski, L. (2015). Versus. O dwoistości strukturalnej faz rozwoju w ekologii cyklu życia psychodynamicznego modelu Erika H. Eriksona. Kraków: Impuls.

Wittgenstein, L. (1922/2012). Tractatus logico-philosophicus. Warszawa: PWN.

Ziółkowski, M. (1990). Orientacje indywidualne a system społeczny. In: J. Rejkowski, K. Skarżyńska, M. Ziółkowski (eds.), Orientacje społeczne jako element mentalności (pp. 53-76). Poznań: Wydawnictwo Nakom. 